\title{
Analisis Unjuk Kerja TCP Window Size 64k Menggunakan Algoritma TCP New Reno pada Jaringan Wired dan Wireless
}

\author{
Salman' ${ }^{1}$ Jafaruddin Gusti Amri Ginting ${ }^{2}$, Reni Dyah Wahyuningrum³ \\ ${ }^{1,2,3)}$ Program Studi S1 Teknik Telekomunikasi, Institut Teknologi Telkom Purwokerto \\ Jl. D.I. Panjaitan No. 128, Purwokerto Selatan 53147 \\ salmanmen98@gmail.com
}

\begin{abstract}
ABSTRAK
Kemacetan Kemacetan jaringan merupakan masalah serius di jaringan internet yang dapat menimbulkan peningkatan jumlah packet loss. Kemacetan juga dapat menjadi beban jaringan sehingga dapat memperlambat koneksi jika tidak ditangani dengan baik, bahkan dapat menyebabkan kelumpuhan dalam jaringan. Transport Control Protocol (TCP) menyediakan mekanisme transfer data yang dapat diandalkan (reliable), sehingga aliran data yang dibaca TCP receiver tidak rusak, tanpa duplikasi, dan berurutan. Pada penelitian ini, penulis melakukan simulasi menggunakan TCP Window Size 64K dengan Algoritma TCP New Reno pada Wired Fast Ethernet dan Wireless 802.11n. Penelitian ini melakukan simulasi untuk mengatasi kemacetan pada jaringan wired dan wireless lalu membandingkan hasil dari parameter Quality of Service (QoS) yang diuji diantaranya adalah throughput, delay, jitter, dan packet loss. Proses simulasi penelitian ini menggunakan Software Riverbed sebagai simulator untuk merancang dan mencari nilai parameter QoS pada jaringan wired dan wireless tersebut. Hasil dari penelitian ini menunjukkan bahwa throughput dan delay yang dihasilkan pada jaringan Wireless 802.11n memiliki performa yang lebih baik daripada Wired Fast Ethernet dengan nilai throughput 13050,6 bit/sec dan nilai delay 0,000253344 sec. Adapun jaringan Wired Fast Ethernet memiliki performa jitter dan packet loss yang lebih baik daripada Wireless 802.11 dengan nilai jitter 0,0000000000003 sec dan nilai packet loss $0 \%$.
\end{abstract}

Kata Kunci: Wired Fast Ethernet, Wireless 802.11n, TCP Window Size 64K, TCP New Reno, Quality of Service (QoS)

\begin{abstract}
Congestion Network congestion is a serious problem in internet networks that can cause an increase in the number of packet loss. Congestion can also become a burden on the network so that it can slow down the connection if not handled properly, and can even cause paralysis in the network. The Transport Control Protocol (TCP) provides a reliable data transfer mechanism, so that the data streams that are read by the TCP receiver are not damaged, without duplication, and sequential. In this study, the authors simulated using TCP Window Size 64K with the New Reno TCP Algorithm on Wired Fast Ethernet and Wireless 802.11n. This study conducted a simulation to solve congestion on wired and wireless networks and then compared the results of the Quality of Service (QoS) parameters tested, including throughput, delay, jitter, and packet loss. The simulation process of this research uses Riverbed Software as a simulator to design and find the QoS parameter values on the wired and wireless networks. The results of this study indicate that the resulting throughput and delay on the Wireless 802.11n network has better performance than Wired Fast Ethernet with a throughput value of 13050.6 bits / sec and a delay value of 0.000253344 sec. The Wired Fast Ethernet network has better jitter and packet loss performance than Wireless $802.11 \mathrm{n}$ with a jitter value of $0.0000000000003 \mathrm{sec}$ and a packet loss value of $0 \%$.
\end{abstract}

Keywords: wired fast ethernet, wireless 802.11n, tcp window size 64k, tcp new reno, quality of service (qos)

\section{PENDAHULUAN}

Pada saat ini, berbagai aktivitas manusia tidak lepas dari jaringan internet. Komunikasi dan pertukaran informasi saat ini pengguna sangat menuntut kecepatan pengiriman, keamanan, dan juga jaminan agar informasi sampai kepada penerima secara utuh. Penelitian dan pengembangan teknologi di bidang telekomunikasi khususnya internet berkembang dengan pesat. Berbagai inovasi dilakukan oleh banyak peneliti untuk menciptakan suatu teknologi jaringan yang efisien dalam melakukan komunikasi. Pengembangan tidak berhenti pada suatu titik saja, tetapi dilakukan secara terus menerus untuk memenuhi kebutuhan informasi yang semakin banyak dan juga cepat. Media transmisi saat ini 
RESISTOR (Elektronika Kendali Telekomunikasi Tenaga Listrik Komputer) Vol. 4 No. 1 e-ISSN : 2621-9700, p-ISSN : 2654-2684

terbagi menjadi dua bagian yaitu jaringan kabel wired dan jaringan wireless.

IEEE (Institute of Electrical Electronics Engineers) 802.11n dikeluarkan pada tahun 2009 dan baru di produksi perangkat maupun device nya baru-baru ini. Standart ini secara teori mampu mentrasferkan kecepatan data hingga $600 \mathrm{Mbps}$ tetapi ketika di uji coba oleh WiFi alliance yaitu badan yang menguji standart ini kecepatan nya hanya 450 Mbps[2].

Fast Ethernet merupakan salah satu tipe ethernet yang mempunyai kecepatan hingga 100 Mbps, dan telah disetujuti oleh IEEE802.3u dengan standarisasi yang digunakan adalah 100BaseFX, 100BaseT, 100BaseT4, 100BaseTX. Fast Ethernet merupakan teknologi jaringan yang masih banyak digunakan saat ini [3].

Transmission Control Protocol (TCP) Window Size 64K merupakan salah satu ukuran TCP Window yang memiliki kinerja yang lebih baik dan lebih stabil terhadap response yang diberikan dibandingkan TCP Window Size yang lainnya dikarenakan semakin besar ukuran TCP Window Size maka semakin besar data yang dapat ditransmisikan [4].

TCP New Reno merupakan pengembangan dari TCP Reno yang hanya dapat menangani satu segmen paket data yang hilang sehingga dapat menangani pengiriman ulang paket data hilang lebih dari satu dalam satu window tanpa menurunkan nilai threshold [5].

RIVERBED dapat digunakan untuk meneliti kinerja jaringan wired dan wireless. Software ini memiliki kelebihan-kelebihan untuk mendesain jaringan berdasarkan perangkat yang ada di pasaran, protokol, layanan, dan teknologi yang sedang trend di dunia telekomunikasi. Riverbed Modeler mengakselerasikan $R \& D$ network, mengurangi time-to-market, dan meningkatkan kualitas produk [6].

Ada beberapa layanan yang digunakan dalam melakukan komunikasi data. Dalam penelitian ini akan menggunakan layanan komunikasi data yang digunakan salah satunya adalah layanan File Transfer Protocol (FTP). Media transmisi yang digunakan yaitu kabel wired dan wireless. Metode transmisi yang digunakan yaitu TCP Window size $64 \mathrm{~K}$ dengan metode penelitian ini menggunakan algoritma TCP New Reno. Simulasi yang akan digunakan untuk melakukan pengujian layanan yaitu software RIVERBED Modeler 17.5. Pengujian dilakukan dengan menganalisis beberapa parameter yang digunakan untuk mengetahui QoS jaringan yang diberikan. Parameter tersebut diantaranya Throughput, Delay, Jitter, dan Packet Loss.

Atas dasar permasalahan performansi sistem wired dan wireless, maka penelitian ini melakukan analisis perbandingan terhadap media transmisi kabel Wired fast ethernet dan Wireless 802.11n. Analisis perbandingan digunakan untuk mengetahui nilai QoS dari TCP Window Size 64K dengan algoritma TCP New Reno pada jaringan Wired Fast Ethernet dan Wireless 802.11N. Maka dari itu penulis mengambil judul "Analisis Unjuk Kerja TCP Window Size 64K Menggunakan Algoritma TCP New Reno pada Jaringan Wired dan Wireless".

\section{METODOLOGI PENELITIAN ALUR PENELITIAN}

Penelitian dilakukan dengan melakukan beberapa tahap yaitu tahap pengumpulan informasi (Studi Literatur), tahap perancangan sistem, tahap perancangan simulasi, tahap pengumpulan data, dan yang terakhir adalah tahap analisis data simulasi.

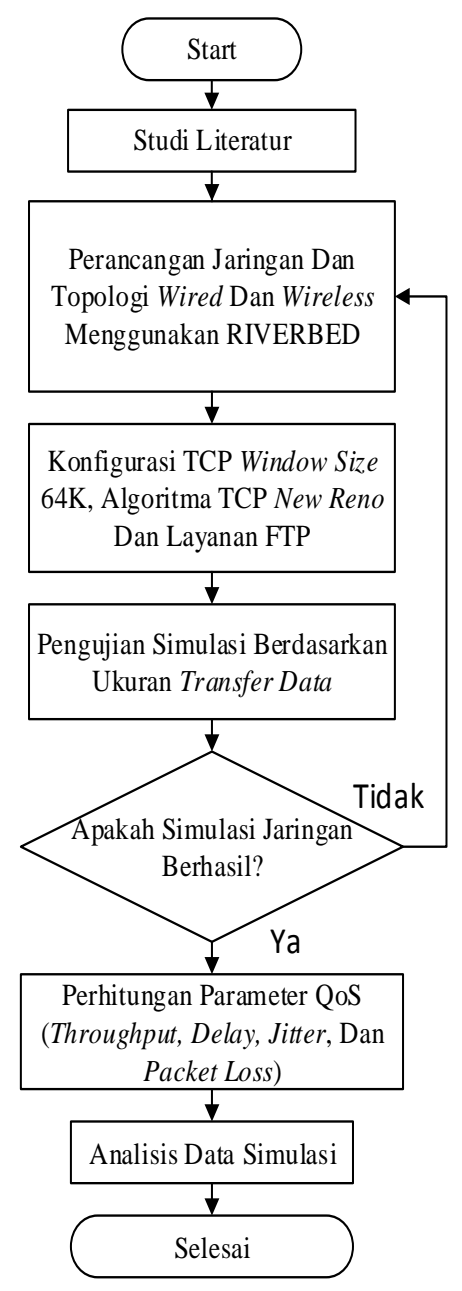


RESISTOR (Elektronika Kendali Telekomunikasi Tenaga Listrik Komputer) Vol. 4 No. 1 e-ISSN : 2621-9700, p-ISSN : 2654-2684

Gambar 1 Flowchart diagram alur penelitian.

Pada Gambar 1.1 menunjukkan flowchart alur kerja dari penelitian yang akan dilakukan dan menunjukkan langkah-langkah untuk penelitian terhadap perbandingan jaringan wired dan wireless pada TCP Window Size 64K. Alur kerja dimulai dengan melakukan studi literatur agar dapat membantu proses pada penelitian ini. Selanjutnya, perancangan jaringan 4 user, 8 user, 16 user, dan 32 user menggunakan topologi star pada wired dan mode infrastruktur pada wireless di simulasi Riverbed modeler 17.5. Pada tahap selanjutnya yaitu konfigurasi metode transmisi TCP Window Size 64K, metode congestion control Algoritma TCP New Reno dan Layanan FTP. Pada tahap selanjutnya dilakukan pengujian besar transfer data sebanyak low load (25\% x Total Bandwidth), medium load (50\% x Total Bandwidth), dan high load (75\% x Total Bandwidth) mengetahui nilai parameter-parameter yang akan dianalisis nantinya. Setelah simulasi dapat berjalan dengan baik kemudian tahap selanjutnya melakukan perhitungan parameter QoS (Throughput, Delay, Jitter, dan Packet Loss). Pada tahap ini parameter QoS yang dapat diambil dari simulasi RIVERBED adalah delay dan packet loss, sedangkan perhitungan throughput dan jitter akan dilakukan menggunakan rumus. Kemudian selanjutnya akan dilakukan analisis data simulasi untuk mengetahui perbandingan jaringan wired dan wireless berdasarkan hasil QoS yang sudah didapatkan

\section{ALAT DAN BAHAN \\ HARDWARE}

Beberapa perangkat hardware yang dibutuhkan untuk melakukan konfigurasi terhadap sistem, diantaranya yaitu laptop yang digunakan untuk melakukan proses simulasi dan software simulasi yaitu menggunakan RIVERBED Modeler.

\section{SOFTWARE}

Perangkat lunak yang digunakan, diantaranya yaitu RIVERBED Modeler merupakan tools simulasi jaringan yang menyediakan Jaringan Virtual Lingkungan dengan model yang seluruh jaringan, termasuk router, switch, protokol, server, dan aplikasi individu. Software yang digunakan pada simulasi jaringan ini menggunakan Software Riverbed Modeler Academic versi 17.5. Software ini digunakan untuk merancang dan membangun simulasi kontrol kepadatan lalu lintas jaringan.

\section{TOPOLOGI JARINGAN}

Pada penelitian ini dilakukan pengujian layanan pada FTP menggunakan Algoritma TCP New Reno. Pengujian dilakukan dengan menggunakan ukuran TCP Window size $64 \mathrm{~K}$ pada jaringan wired dan wireless sehingga mendapatkan nilai dari paramater QoS. Pengujian tersebut bertujuan untuk mengetahui kualitas jaringan yang diberikan. Switch maupun access point tersebut dapat menjadi node tengah agar jaringan komputer dapat terhubung satu sama lain.

Topologi yang digunakan yaitu menggunakan topologi star pada jaringan wired seperti yang ditunjukkan pada Gambar 1.2. Topologi Star pada jaringan wired akan menggunakan switch. Mode infrastruktur pada jaringan wireless ditunjukkan pada Gambar 1.2. Sedangkan infrastruktur yang digunakan pada jaringan wireless adalah access point.

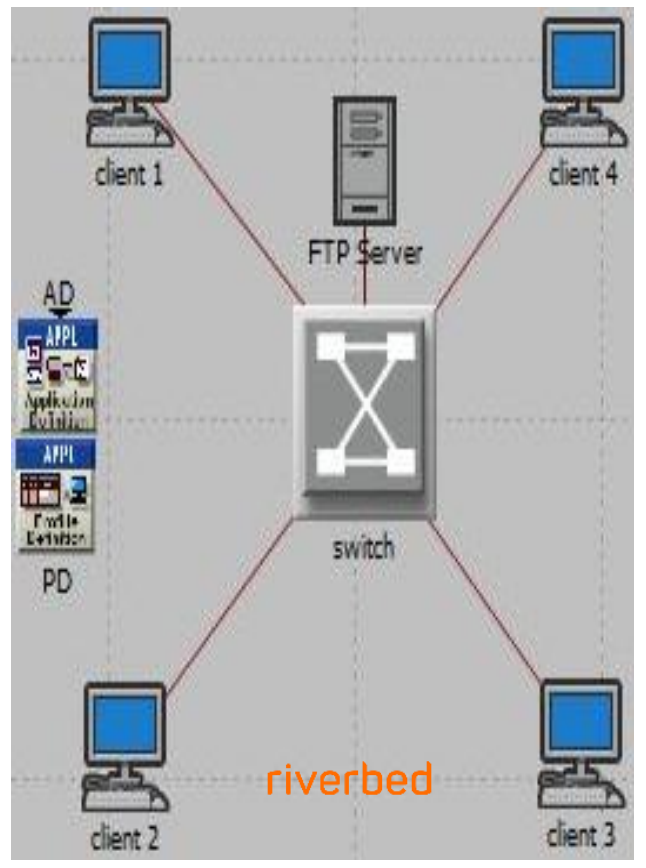

Gambar 2. Topologi jaringan penelitian.

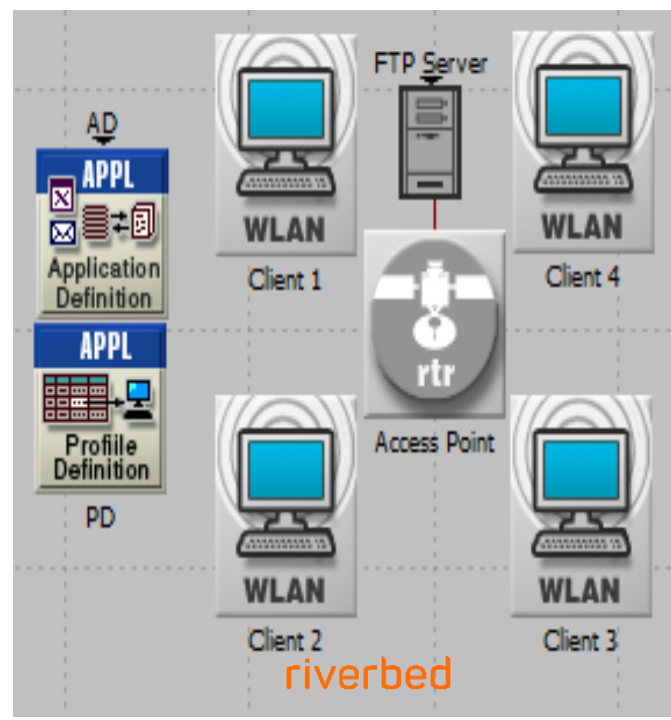


RESISTOR (Elektronika Kendali Telekomunikasi Tenaga Listrik Komputer) Vol. 4 No. 1 e-ISSN : 2621-9700, p-ISSN : 2654-2684

Gambar 3 Perancangan topologi jaringan wireless.

Pada Gambar 1.2 dan 1.3 terdapat beberapa jenis node yang digunakan pada topologi jaringan topologi star. Node tersebut yaitu Application Definiton atau Application Config, Profile Defintion atau Profile Config, dan Komputer Pengguna (User). Application Config merupakan node yang digunakan untuk mengkonfigurasi layanan-layanan yang akan digunakan. Dalam penelitian ini menggunakan layanan FTP. Sedangkan Profile Config merupakan node profile yang digunakan untuk menjalankan layanan yang telah didefinisikan pada node application /.

\section{PARAMETER PENELITIAN}

\section{PARAMETER KINERJA}

Pada penelitian ini penulis telah menentukan beberapa parameter kinerja yang dapat digunakan untuk mengukur unjuk kerja dari layanan aplikasi yang akan diteliti menggunakan TCP Window Size yang berbeda dengan Algoritma TCP Reno. Parameter kinerja ini menjadi fokus dalam setiap pengujian yang dilakukan sebagai berikut :

a) Throughput

Throughput merupakan jumlah total kedatangan paket yang sukses yang diamati pada tujuan selama interval waktu tertentu dibagi oleh durasi interval waktu tersebut. Throughput diukur dalam bps (bit per second).

Perhitungan throughput dinyatakan sebagai

Throughput $=$

Jumlah data yang dikirim

Waktu pengiriman data

b) Delay

Delay yaitu waktu yang dibutuhkan paket untuk mencapai tujuan, karena adanya antrian, atau mengambil rute yang lain untuk menghindari kemacetan yang diukur dalam 's' (second). Delay dapat dipengaruhi oleh jarak, media fisik, kongesti atau juga waktu proses yang lama. Delay

Perhitungan delay dinyatakan sebagai

Waktu penerimaan paket - Waktu pengiriman paket Total Paket yang diterima

c) Jitter

Jitter atau variasi delay, berhubungan erat dengan latency, yang menunjukkan banyaknya variasi delay pada taransmisi data di jaringan. Delay antrian pada router dan switch menyebabkan jitter. Hal ini diakibatkan oleh variasi-variasi panjang antrian, waktu pengolahan data, dan waktu penghimpunan ulang paket-paket di akhir perjalanan jitter.

Perhitungan jitter dinyatakan sebagai
Jitter

Total variasi Delay

Total Packet diterima

d) Packet Loss

Packet Loss merupakan suatu parameter yang menggambarkan suatu kondisi yang menunjukkan jumlah total paket yang hilang, dapat terjadi karena collision dan congestion pada jaringan.

Perhitungan Packet Loss dinyatakan sebagai [19]

Packet Loss $=$

$\frac{\text { (Packet data dikirim-packet data diterima) }}{\text { Packet data dikirim }} \times 100$.

\subsection{PARAMETER PENGUJIAN}

Pada penelitan ini, penulis menentukan parameter yang digunakan dalam melakukan pengujian agar hasil data yang didapatkan sesuai dengan yang diharapkan. Tabel 1.1 menunjukkan parameter pengujian yang digunakan untuk penelitian ini

Tabel 1. Parameter pengujian.

\begin{tabular}{|c|c|c|}
\hline Parameter & Ukuran & Load \\
\hline \multirow{3}{*}{$\begin{array}{l}\text { Wired Fast } \\
\text { Ethernet }\end{array}$} & \multirow{3}{*}{ 100Mbps } & $\begin{array}{l}\text { Load (25\% x Total } \\
\text { Bandwidth }\end{array}$ \\
\hline & & $\begin{array}{l}\text { Load (50\% x Total } \\
\text { Bandwidth) }\end{array}$ \\
\hline & & $\begin{array}{l}\text { Load }(75 \% \text { x Total } \\
\text { Bandwidth) }\end{array}$ \\
\hline \multirow{3}{*}{$\begin{array}{l}\text { Wireless } \\
802.11 \mathrm{n}\end{array}$} & \multirow{3}{*}{$600 \mathrm{Mbps}$} & $\begin{array}{l}\text { Load }(25 \% \times \text { Total } \\
\text { Bandwidth }\end{array}$ \\
\hline & & $\begin{array}{l}\text { Load (50\% x Total } \\
\text { Bandwidth) }\end{array}$ \\
\hline & & $\begin{array}{l}\text { Load (75\% x Total } \\
\text { Bandwidth) }\end{array}$ \\
\hline
\end{tabular}

\section{SKENARIO PENELITIAN}

Mengacu pada topologi jaringan yang dirancang, pengujian sistem dibuat menjadi empat skenario yaitu menggunakan 4 client, 8 client, 16 client, dan 32 client pada layanan aplikasi FTP dengan besar transfer data pada setiap skenario masing-masing sebanyak $(25 \%$ x Total Bandwidth), (50\% x Total Bandwidth), dan (75\% x Total Bandwidth) seperti pada Tabel 3.3. Pengujian ini dilakukan dengan menempatkan media transmisi yang berbeda, yang bertujuan untuk mengetahui kualitas jaringan yang diberikan selama proses simulasi. Hasil keluaran parameter QoS dari 4 skenario yang dirancang, dapat dianalisa untuk perbandingan kualitas pada jaringan wired dan wireless yang telah 
RESISTOR (Elektronika Kendali Telekomunikasi Tenaga Listrik Komputer) Vol. 4 No. 1 e-ISSN : 2621-9700, p-ISSN : 2654-2684

dikonfigurasi TCP Window Size 64K dengan Algoritma TCP New Reno untuk melakukan congestion control yang dilakukan pada layanan FTP. Untuk mempermudah pemahaman mengenai skenario yang dijalankan pada pengujian jaringan ditunjukkan pada Tabel 1.2.

Tabel 2 Skenario pengujian sistem.

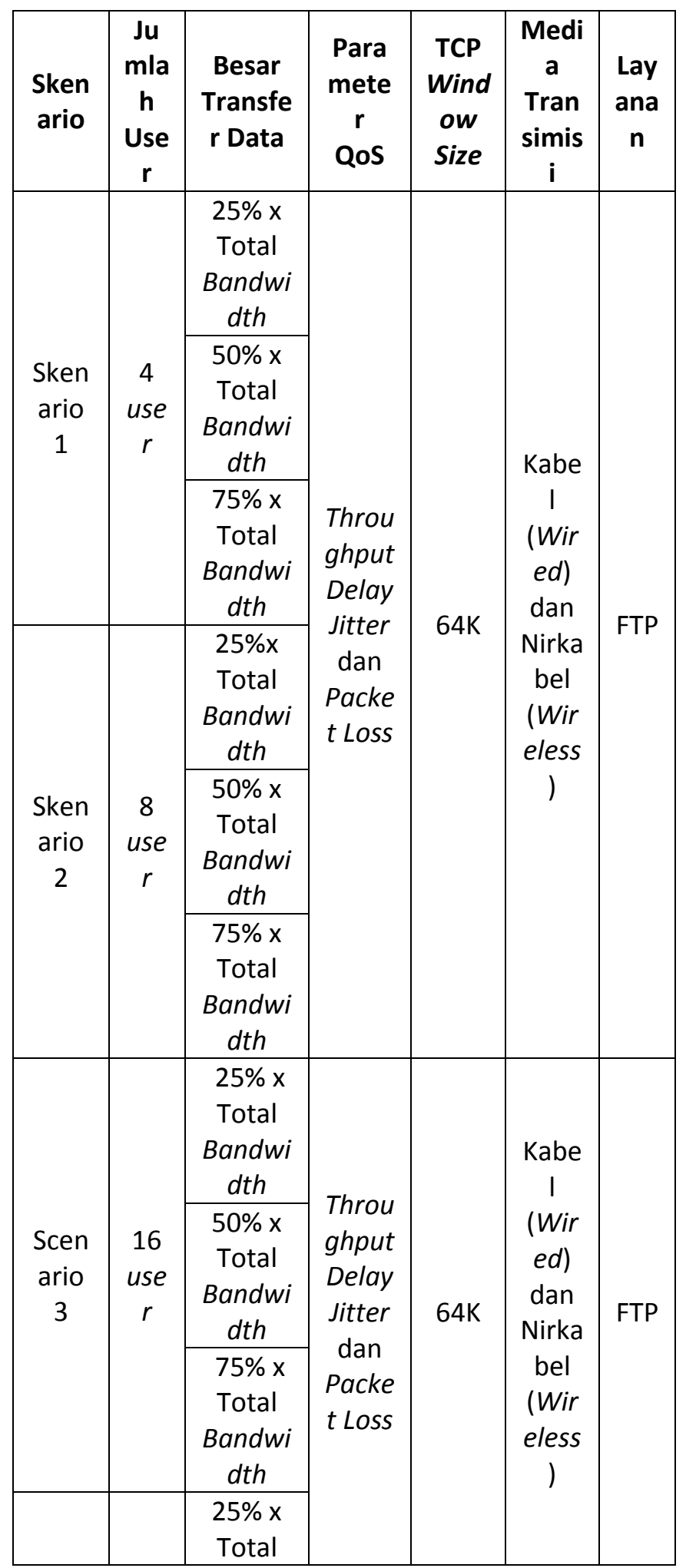

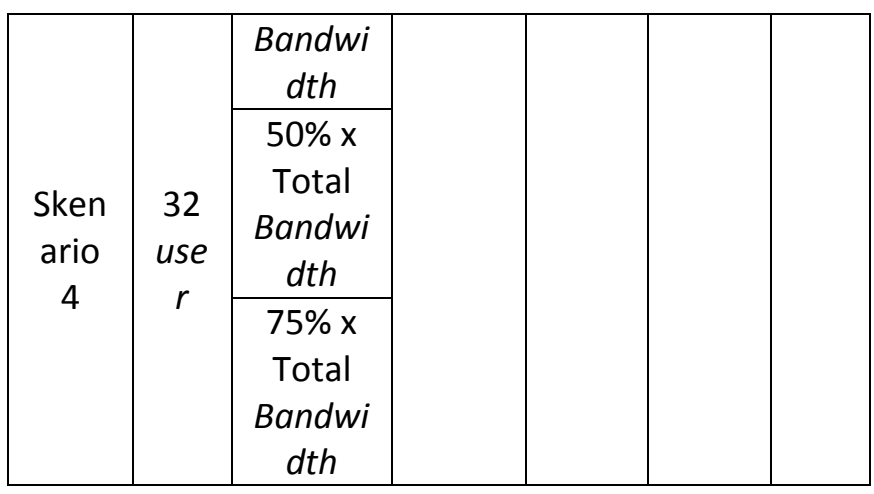

\section{HASIL DAN ANALISA \\ HASIL SIMULASI DAN ANALISA}

Simulasi jaringan pada penelitian ini menggunakan software RIVERBED Modeler Academic versi 17.5 untuk melakukan pengujian pada jaringan wired dan wireless. Hasil simulasi yang akan dianalisa terdiri dari 4 skenario. Dimulai dari Skenario 4 Client, Skenario 8 Client, Skenario 16 Client, dan Skenario 32 Client. Dari masingmasing skenario tersebut akan dilakukan pengujian dengan mengirimkan besar file transfer data sebesar $25 \% \mathrm{x}$ total bandwidth, $50 \% \mathrm{x}$ total bandwidth, dan $75 \% \mathrm{x}$ total bandwidth. Jaringan yang dibuat dalam skenario adalah dengan menggunakan 4 client, 8 client, 16 client, dan 32 client dan 1 buah server untuk layanan File Transfer Protocol (FTP). Kemudian pada jaringan wired akan ditambahkan sebuah switch untuk menghubungkan antara client dan server menggunakan kabel fast ethernet. Sedangkan pada jaringan wireless akan ditambahkan sebuah access point untuk menghubungkan dari server menggunakan kabel fast ethernet ke access point, kemudian dari access point akan dihubungkan ke client menggunakan wireless $802.11 \mathrm{n}$.

Besar transfer data $25 \%$ x total bandwidth diperoleh dengan mencari $25 \%$ dari total bandwidth pada jaringan wired fast ethernet dan wireless $802.11 \mathrm{n}$ lalu dibagi jumlah client. Pada Skenario 4 Client diperoleh nilai transfer data setiap client yaitu sebesar 819.200 Byte pada jaringan wired fast ethernet. Sedangkan nilai transfer data pada jaringan wireless 802.11n adalah sebesar 495.200 Byte. Pada Skenario 8 Client diperoleh nilai transfer data setiap client sebesar 409.600 Byte dan pada jaringan wireless sebesar 2.457.600 Byte. Kemudian pada Skenario 16 Client diperoleh nilai transfer data setiap client sebesar 204.800 Byte dan pada jaringan wireless sebesar 1.228.800 Byte. Pada Skenario 32 Client diperoleh nilai transfer data setiap client sebesar 102.400 Byte dan pada jaringan wireless sebesar 614.400 Byte. 
RESISTOR (Elektronika Kendali Telekomunikasi Tenaga Listrik Komputer) Vol. 4 No. 1 e-ISSN : 2621-9700, p-ISSN : 2654-2684

Besar transfer data $50 \%$ x total bandwidth diperoleh dengan mencari $50 \%$ dari total bandwidth pada jaringan wired fast ethernet dan wireless $802.11 \mathrm{n}$ lalu dibagi jumlah client. Pada Skenario 4 Client diperoleh nilai transfer data setiap client yaitu sebesar 1.638.400 Byte pada jaringan wired fast ethernet. Sedangkan nilai transfer data pada jaringan wireless $802.11 \mathrm{n}$ adalah sebesar 9.830.400 Byte. Pada Skenario 8 Client diperoleh nilai transfer data setiap client sebesar 819.200 Byte dan pada jaringan wireless sebesar 4.915.200 Byte. Kemudian pada Skenario 16 Client diperoleh nilai transfer data setiap client sebesar 409.600 Byte dan pada jaringan wireless sebesar 2.457.600 Byte. Pada Skenario 32 Client diperoleh nilai transfer data setiap client sebesar 204.800 Byte dan pada jaringan wireless sebesar 1.228.800 Byte.

Besar transfer data $75 \%$ x total bandwidth diperoleh dengan mencari $75 \%$ dari total bandwidth pada jaringan wired fast ethernet dan wireless $802.11 \mathrm{n}$ lalu dibagi jumlah client. Pada Skenario 4 Client diperoleh nilai transfer data setiap client yaitu sebesar 2.457.600 Byte pada jaringan wired fast ethernet. Sedangkan nilai transfer data pada jaringan wireless $802.11 \mathrm{n}$ adalah sebesar 14.745.600 Byte. Pada Skenario 8 Client diperoleh nilai transfer data setiap client sebesar 1.228.800 Byte dan pada jaringan wireless sebesar 7.372.800 Byte. Kemudian pada Skenario 16 Client diperoleh nilai transfer data setiap client sebesar 614.400 Byte dan pada jaringan wireless sebesar 3.686.400 Byte. Pada Skenario 32 Client diperoleh nilai transfer data setiap client sebesar 307.200 Byte dan pada jaringan wireless sebesar 1.843.200 Byte.

Hasil yang didapatkan dari simulasi berupa grafik dalam bentuk linear. Kemudian akan dilakukan perbandingan parameter throughput, delay, jitter, dan packet loss pada jaringan wired dan wireless dari masing-masing skenario. Grafik tersebut ditampilkan dengan perbedaan warna yang masing-masing warna merepresentasikan hasil output parameter client. Analisa perbandingan ini akan lebih fokus pada hasil output parameter Quality of Service (QoS) yang memperlihatkan perbedaan kualitas performa layanan FTP pada jaringan wired dan wireless menggunakan Transmission Control Protocol Window Size 64K, juga mekanisme congestion control yang ada pada Transmission Control Protocol New Reno.

\section{PARAMETER THROUGHPUT}

Throughput merupakan jumlah berapa banyak data yang dapat ditransfer dari sumber ke tujuannya dalam jangka waktu tertentu.
Throughput mengukur tingkat keberhasilan pesan sampai di tujuannya. Semakin besar nilai throughput, maka akan semakin baik. Besarnya throughput akan mempengaruhi kualitas kinerja jaringan tersebut.

\section{SKENARIO 32 CLIENT}

Skenario 32 client dilakukan pada 32 client dengan besar transfer data yang berbeda-beda pada jaringan wired fast ethernet dan wireless $802.11 \mathrm{n}$. Besar transfer data yang dilakukan yaitu $25 \%$ x Total Bandwidth, 50\% x Total Bandwidth, dan $75 \%$ x Total Bandwidth.

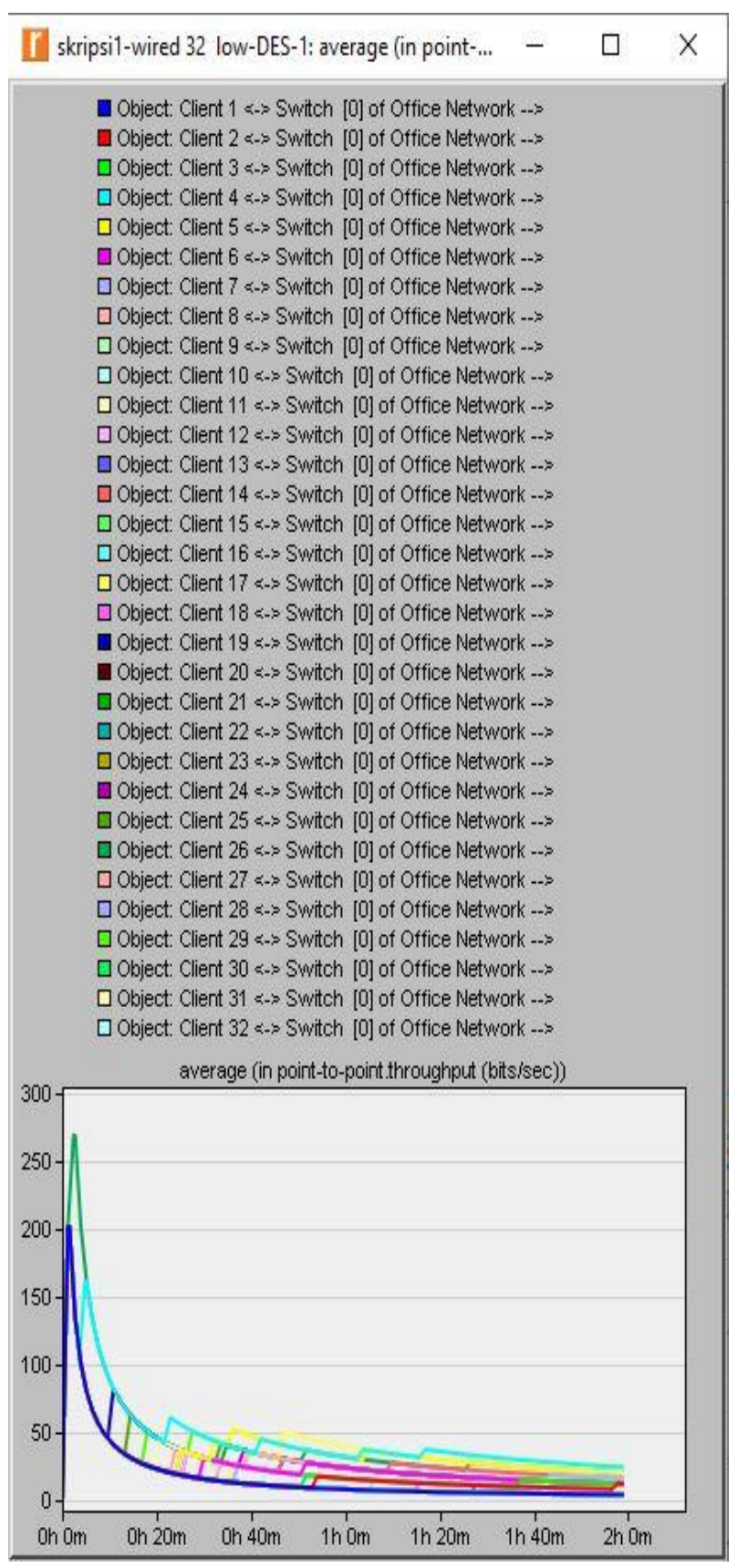

(a) 
RESISTOR (Elektronika Kendali Telekomunikasi Tenaga Listrik Komputer) Vol. 4 No. 1 e-ISSN : 2621-9700, p-ISSN : 2654-2684

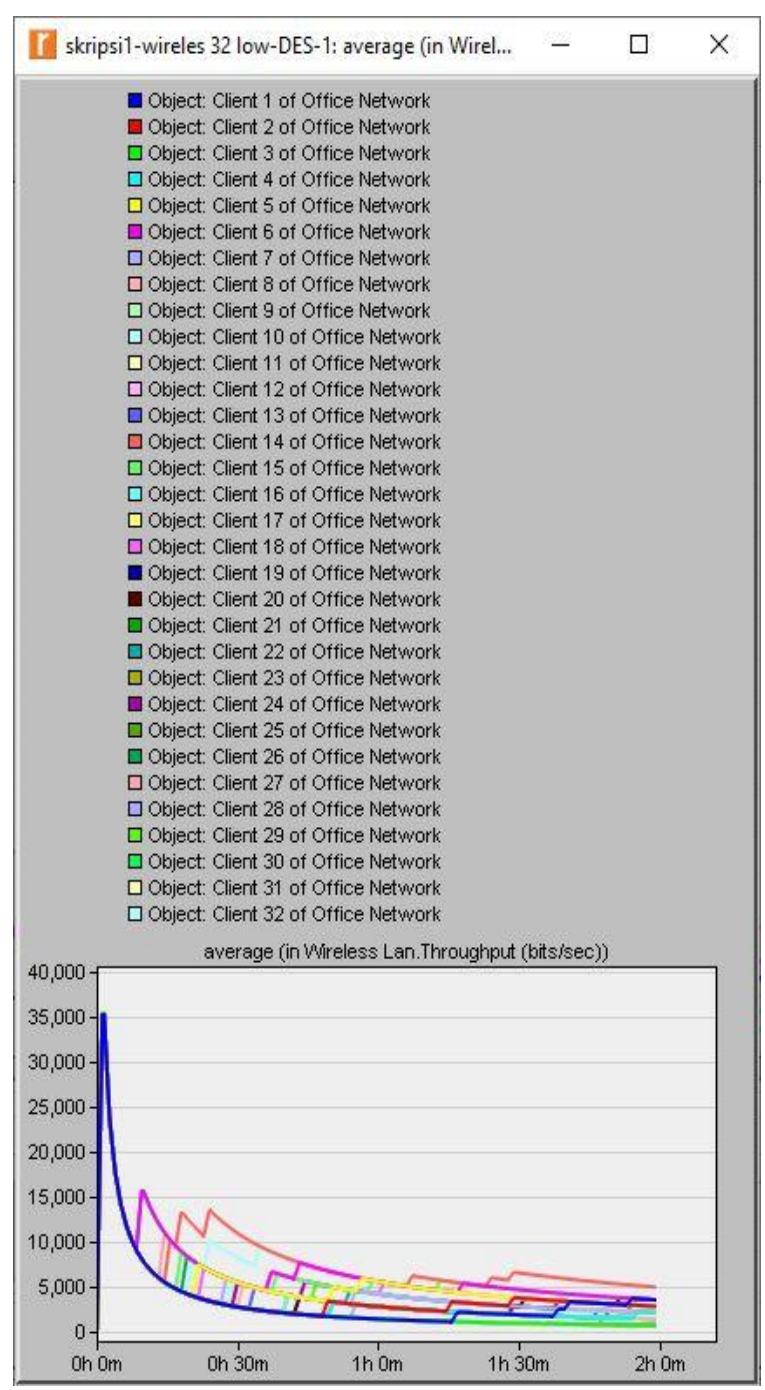

(b)

Gambar 4 Perbandingan throughput (a) transfer data $75 \%$ dari total bandwidth fast ethernet;

(b) transfer data $75 \%$ dari total bandwidth wireless $802.11 \mathrm{n}$.

Pada Gambar 4 (a) dan (b) menunjukkan perbedaan grafik nilai throughput yang dihasilkan dari software simulasi riverbed pada jaringan fast ethernet dan wireless $802.11 \mathrm{n}$. Pada sumbu $\mathrm{x}$ mewakili duration (hour) sedangkan pada sumbu y mewakili nilai throughput (bit/sec).

Pada Gambar 4 terdapat client yang menampilkan mekanisme congestion dan ada yang tidak. Mekanisme TCP New Reno dalam melakukan congestion control adalah dengan adanya fase slow start, fase fast retransmit, fase fast recovery dan congestion avoidance. Adapun client yang tidak memiliki congestion hanya mengalami fase slow start saja. Fase slow start terjadi dengan adanya kenaikan nilai throughput dimana TCP mencoba mengetahui kapasitas ruang buffer yang dimiliki oleh penerima. Selanjutnya pada fase fast retransmit dan fase fast recovery. Fase ini terjadi dengan ada nya penurunan nilai throughput yang disebabkan adanya packet drop yang terjadi saat pengiriman packet. Selanjutnya pada fase congestion avoidance. Fase ini terjadi dengan adanya kenaikan nilai throughput secara linier dimana TCP berusaha menghindari kemacetan saat proses pengiriman paket.

Berdasarkan pada gambar tersebut, average kejadian fase slow start pada simulasi 32 client dengan transfer data $75 \%$ dari total bandwidth terjadi pada detik 0-144 sec pada jaringan fast ethernet dengan nilai throughput $531.366 \mathrm{bits} / \mathrm{sec}$ dan terjadi pada detik 0-72 sec pada jaringan wireless $802.11 \mathrm{n}$ dengan nilai throughput 116145 bits/sec.

Setelah mengalami fase slow start, kemudian TCP akan menurunkan jumlah packet yang dikirimkan untuk menghindari congestion. Setelah itu, Jika packet terus turun hingga simulasi berakhir, maka client tidak mengalami congestion. Adapun jika terjadi congestion, maka terjadi fase restransmit dan fase fast recovery. Average kejadian fase restransmit dan fase fast recovery pada simulasi 32 client dengan transfer data $75 \%$ dari total bandwidth terjadi pada detik 360-5328 sec pada jaringan fast ethernet dengan nilai throughput 49.4757 bits/sec dan terjadi pada detik 216-6408 sec pada jaringan wireless 802.11n dengan nilai throughput $14781.5 \mathrm{bits} / \mathrm{sec}$.

Setelah mengalami fase restransmit dan fase fast recovery, kemudian TCP akan menaikkan jumlah packet yang dikirimkan untuk menghindari packet loss yang disebut fase congestion avoidance. Average kejadian fase congestion avoidance pada simulasi 32 client dengan transfer data $75 \%$ dari total bandwidth terjadi pada detik 504-5400 sec pada jaringan fast ethernet dengan nilai throughput $94.8989 \mathrm{bits} / \mathrm{sec}$ dan terjadi pada detik 288-6480 sec pada jaringan wireless 802.11n dengan nilai throughput 23899.6 bits/sec. Selanjutnya, packet akan kembali turun hingga simulasi berakhir.

\section{PARAMETER DELAY}

Delay merupakan total waktu yang dilalui suatu paket dari pengirim ke penerima melalui jaringan. Jumlah waktu yang dibutuhkan untuk menunggu tergantung pada besaran antrian. Jika antrian kosong, maka akan ditransmisikan segera, tetapi jika paket tersebut berada di belakang paket lain, maka perlu menunggu paket di depan untuk ditransmisikan terlebih dahulu. Semakin kecil nilai delay, maka akan semakin baik kualitas jaringan tersebut. 
RESISTOR (Elektronika Kendali Telekomunikasi Tenaga Listrik Komputer) Vol. 4 No. 1 e-ISSN : 2621-9700, p-ISSN : 2654-2684

\section{SKENARIO 4 CLIENT}

Skenario 4 client dilakukan pada 4 client dengan besar transfer data yang berbeda-beda pada jaringan wired fast ethernet dan wireless $802.11 \mathrm{n}$. Besar transfer data yang dilakukan yaitu 25\% x Total Bandwidth, 50\% x Total Bandwidth, dan $75 \%$ x Total Bandwidth.

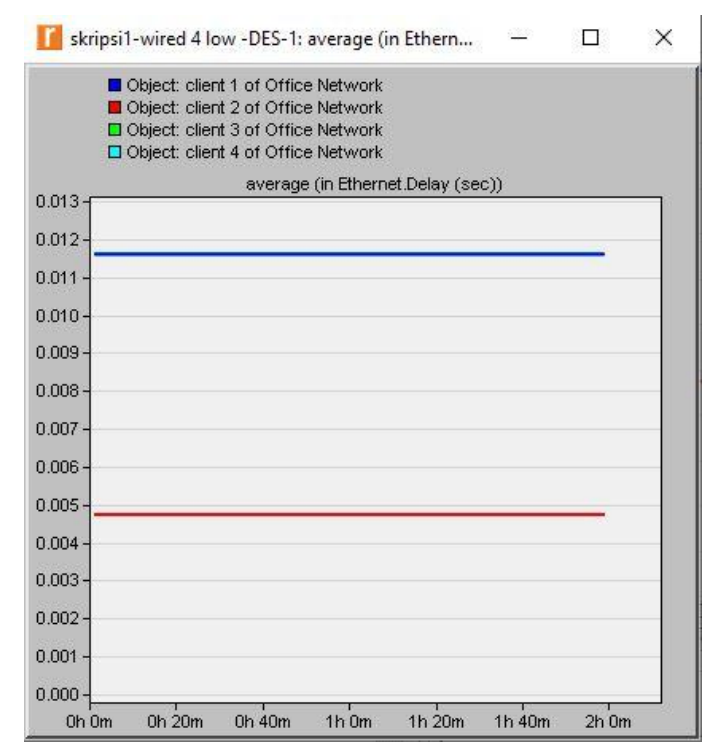

(a)

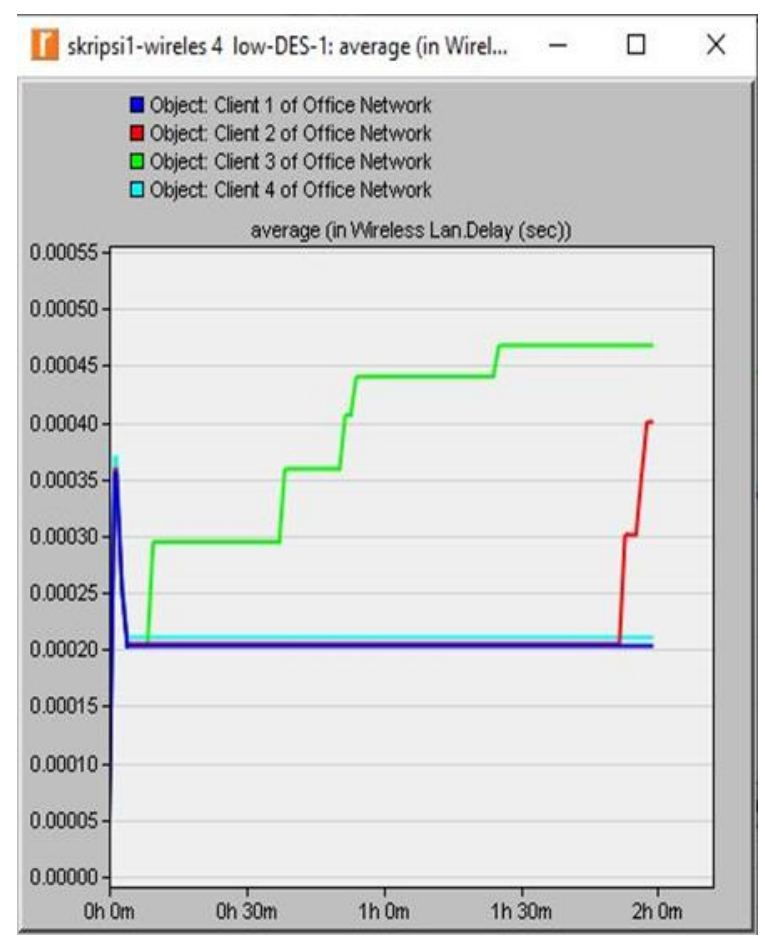

(b)
Gambar 5 Perbandingan delay (a) transfer data $25 \%$ dari total bandwidth fast ethernet; (b) transfer data $25 \%$ dari total bandwidth wireless $802.11 \mathrm{n}$;

Pada Gambar 5 (a) dan (b) menunjukkan perbedaan grafik nilai delay yang dihasilkan dari software simulasi riverbed pada jaringan fast ethernet dan wireless $802.11 \mathrm{n}$. Pada sumbu $\mathrm{x}$ mewakili duration (hour) sedangkan pada sumbu y mewakili nilai delay $(\mathrm{sec})$.

Pada Gambar 5 menampilkan mekanisme congestion control diantaranya : slow start, fast retransmit, fast recovery dan congestion avoidance. Average kejadian fase slow start pada simulasi 4 client dengan transfer data $25 \%$ dari total bandwidth terjadi pada detik 0-72 sec pada jaringan fast ethernet dengan nilai delay $0.009887067 \mathrm{sec}$ dan jaringan wireless $802.11 \mathrm{n}$ dengan nilai delay $0.000360804 \mathrm{sec}$.

Average kejadian fase fast restransmit dan fase fast recovery pada simulasi 4 client dengan transfer data $25 \%$ dari total bandwidth terjadi pada detik 2088-6840 sec pada jaringan fast ethernet dengan nilai delay 0.011603119 sec dan terjadi pada detik 504-6696 sec pada jaringan wireless 802.11n dengan nilai delay 0.000204209 sec.

Average kejadian fase congestion avoidance pada simulasi 4 client dengan transfer data 25\% dari total bandwidth terjadi pada detik 2160-6912 sec pada jaringan fast ethernet dengan nilai delay $0.011602978 \mathrm{sec}$ dan terjadi pada detik 576-6768 sec pada jaringan wireless $802.11 \mathrm{n}$ dengan nilai delay $0.000297695 \mathrm{sec}$.

\section{PARAMETER JITTER}

Jitter merupakan variasi dari delay yang diakibatkan oleh variasi-variasi dalam panjang antrian, dalam waktu pengolahan data, dan juga dalam waktu penghimpunan ulang paket-paket di akhir perjalanan jitter. Jitter yang terjadi mendekati nol maka kecepatan jaringan tersebut dikatakan baik. Namun sebaliknya jika tidak mendekati nol maka kecepatan pengiriman data dapat dikatakan kurang baik dan akan terjadi kehilangan data dalam proses pengiriman data/packet loss.

\section{SKENARIO 4 CLIENT}

Skenario 4 client dilakukan pada 4 client dengan besar transfer data yang berbeda-beda pada jaringan wired fast ethernet dan wireless 802.11 n. Besar transfer data yang dilakukan yaitu 25\% x Total Bandwidth, 50\% x Total Bandwidth, dan $75 \%$ x Total Bandwidth. 
RESISTOR (Elektronika Kendali Telekomunikasi Tenaga Listrik Komputer) Vol. 4 No. 1 e-ISSN : 2621-9700, p-ISSN : 2654-2684

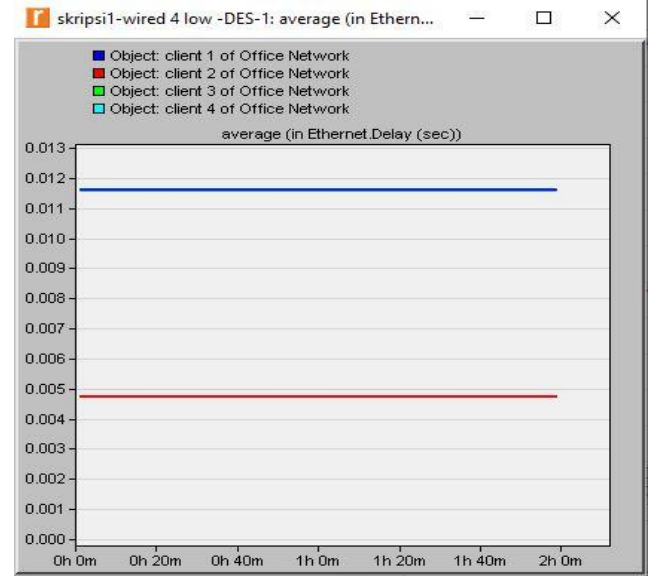

(a)

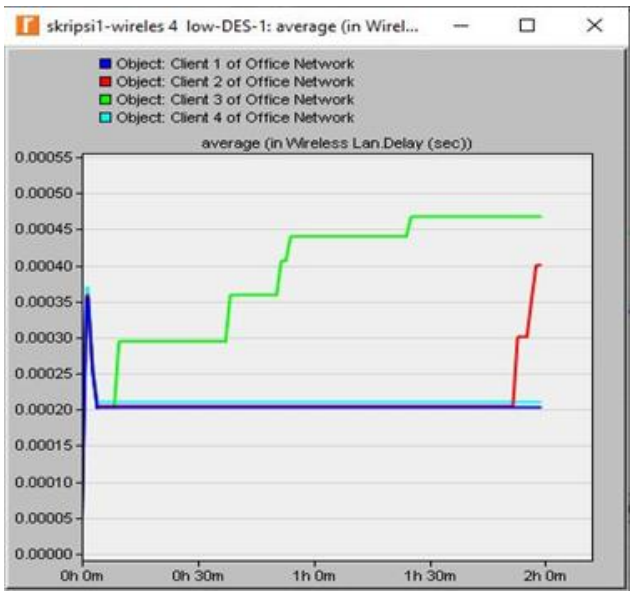

(b)

Gambar 6 Perbandingan Jitter (a) Transfer Data 75\% dari Total Bandwidth Fast Ethernet; (b) Transfer Data 75\% dari Total Bandwidth Wireless 802.11n.

Pada Gambar 6 (a) dan (b) menunjukkan perbedaan grafik nilai jitter yang dihasilkan dari software simulasi riverbed pada jaringan fast ethernet dan wireless 802.11n. Pada sumbu $\mathrm{x}$ mewakili duration (hour) sedangkan pada sumbu y mewakili nilai jitter (sec).

Pada Gambar 6 menampilkan mekanisme congestion control diantaranya : slow start, fast retransmit, fast recovery dan congestion avoidance.

Average kejadian fase slow start pada simulasi 4 client dengan transfer data $75 \%$ dari total bandwidth terjadi pada detik 0-72 sec pada jaringan fast ethernet dengan nilai jitter 0 sec dan terjadi pada detik 0-144 sec pada jaringan wireless $802.11 \mathrm{n}$ dengan nilai jitter $0.000103817 \mathrm{sec}$.

Average kejadian fase fast restransmit dan fase fast recovery pada simulasi 4 client dengan transfer data $75 \%$ dari total bandwidth terjadi pada detik 1800-5832 sec pada jaringan fast ethernet dengan nilai jitter $0.00000000002 \mathrm{sec}$ dan terjadi pada detik 288-6768 sec pada jaringan wireless $802.11 \mathrm{n}$ dengan nilai jitter $0.000078 \mathrm{sec}$.

Average kejadian fase congestion avoidance pada simulasi 4 client dengan transfer data $75 \%$ dari total bandwidth terjadi pada detik 1872-5904 sec pada jaringan fast ethernet dengan nilai jitter 0 sec dan terjadi pada detik 360-6840 sec pada jaringan wireless $802.11 \mathrm{n}$ dengan nilai jitter $0 \mathrm{sec}$.

\section{PARAMETER PACKET LOSS}

Packet loss adalah besar kegagalan saat mentransmisikan suatu paket data kepada alamat tujuan yang menyebabkan hilangnya beberapa data dalam proses pengiriman. Packet loss biasanya diberi satuan dalam bentuk persen (\%) untuk menandai berapa persen jumlah paket yang tidak dapat dikirimkan dari total keseluruhan semua paket. Semakin kecil jumlah packet loss yang didapatkan maka semakin baik pula jaringan tersebut untuk digunakan.

\section{SKENARIO 4 CLIENT}

Skenario 4 client dilakukan pada 4 client dengan besar transfer data yang berbeda-beda pada jaringan wired fast ethernet dan wireless $802.11 \mathrm{n}$. Besar transfer data yang dilakukan yaitu $25 \%$ x Total Bandwidth, 50\% x Total Bandwidth, dan $75 \%$ x Total Bandwidth.

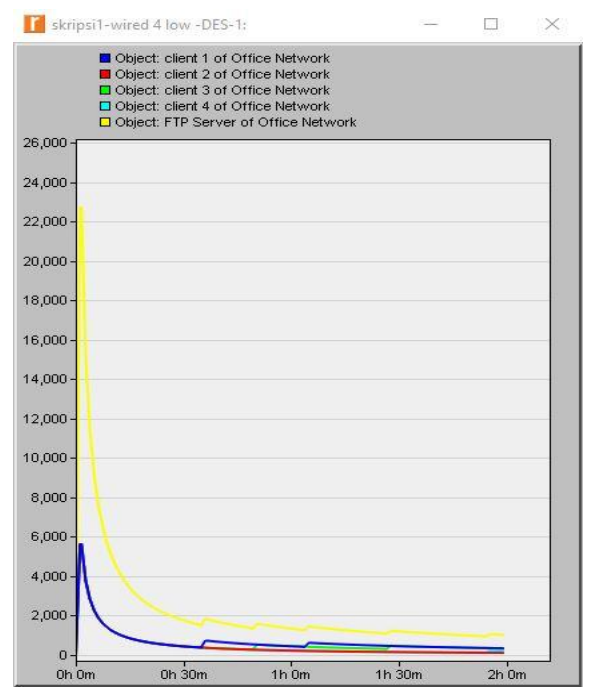

(a) 
RESISTOR (Elektronika Kendali Telekomunikasi Tenaga Listrik Komputer) Vol. 4 No. 1 e-ISSN : 2621-9700, p-ISSN : 2654-2684

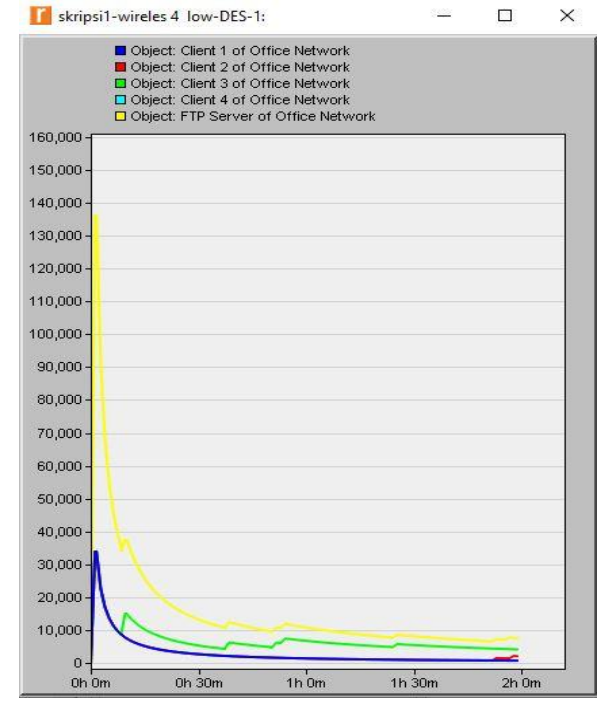

(b)

Gambar 7. Perbandingan packet loss ftp (a) transfer data $75 \%$ dari total bandwidth fast ethernet; (b) transfer data $75 \%$ dari total bandwidth wireless $802.11 \mathrm{n}$.

Pada Gambar 7. (a) dan (b) menunjukkan perbedaan grafik nilai traffic sent dan traffic received dari software simulasi riverbed pada jaringan fast ethernet dan wireless $802.11 \mathrm{n}$. Pada sumbu x mewakili duration (hour) sedangkan pada sumbu y mewakili nilai packet loss (\%).

Pada Gambar 7. menampilkan mekanisme adanya packet loss pada grafik yang dimiliki oleh penerima. menunjukkan perbedaan nilai packet loss yang dihasilkan pada jaringan fast ethernet dan wireless $802.11 \mathrm{n}$. Average nilai packet loss pada simulasi 4 client dengan transfer data 75\% dari total bandwidth adalah $0 \%$ pada jaringan fast ethernet dan $0.465909091 \%$ pada jaringan wireless 802.11 n.

\section{PERBANDINGAN HASIL ANALISA DAN SIMULASI}

Berikut ini merupakan perbedaan hasil keseluruhan average dari simulasi yang diteliti dapat dilihat pada tabel 4 berupa nilai average throughput,delay, jitter dan packet loss. Pada keseluruhan nilai average throughput dan delay, wireless 802.11n memiliki performa yang lebih baik daripada jaringan wired fast ethernet. Namun pada keseluruhan nilai jitter dan packet loss, wired fast ethernet lebih baik daripada wireless 802.11n. Adapun secara keseluruhan hasil simulasi, jaringan wireless $802.11 \mathrm{n}$ memiliki delay yang lebih cepat daripada fast ethernet. Namun fast ethernet memiliki nilai packet loss yang lebih rendah daripada wireless $802.11 \mathrm{n}$. Hal itu dikarenakan wireless $802.11 \mathrm{n}$ memiliki media transmisi yang secara bebas dikirimkan melalui media udara. Hal itu menyebabkan packet data dapat dikirimkan lebih cepat daripada jaringan fast ethernet, namun nilai delay-nya tidak stabil, sehingga rentan terjadinya tabrakan data maupun gangguan yang dapat menyebabkan packet loss. Sedangkan wired fast ethernet memiliki media transmisi yang dikirimkan secara terarah melalui media kabel, sehingga pesan yang dikirimkan jarang terjadi packet loss. Hal itu menyebabkan packet data yang dikirimkan membutuhkan delay yang lebih lama dari wireless $802.11 \mathrm{n}$, namun nilai delay-nya lebih stabil.

Tabel 4. Perbandingan hasil analisa dan simulasi.

\begin{tabular}{|c|c|c|c|c|c|}
\hline No & $\begin{array}{l}\text { Param } \\
\text { eter }\end{array}$ & $\begin{array}{l}\text { Jumla } \\
\mathrm{h} \\
\text { Client }\end{array}$ & $\begin{array}{l}\text { Besar } \\
\text { Transfer } \\
\text { Data }\end{array}$ & $\begin{array}{l}\text { Media } \\
\text { Transmisi }\end{array}$ & $\begin{array}{l}\text { Nilai } \\
\text { Averag } \\
\mathrm{e} \\
\end{array}$ \\
\hline \multirow[t]{22}{*}{1.} & \multirow{22}{*}{$\begin{array}{l}\text { Throu } \\
\text { ghput } \\
\text { (bit/s) }\end{array}$} & \multirow{6}{*}{4} & \multirow{2}{*}{$\begin{array}{l}25 \% \quad \mathrm{x} \\
\text { Total } \\
\text { Bandwid } \\
\text { th }\end{array}$} & $\begin{array}{l}\text { Fast } \\
\text { Ethernet }\end{array}$ & 4743.51 \\
\hline & & & & $802.11 n$ & 31695 \\
\hline & & & \multirow{2}{*}{$\begin{array}{l}50 \% \quad \mathrm{x} \\
\text { Total } \\
\text { Bandwid } \\
\text { th }\end{array}$} & $\begin{array}{l}\text { Fast } \\
\text { Ethernet }\end{array}$ & $\begin{array}{l}9950.45 \\
85 \\
\end{array}$ \\
\hline & & & & $802.11 n$ & 70442.9 \\
\hline & & & \multirow{2}{*}{$\begin{array}{l}75 \% \quad \mathrm{x} \\
\text { Total } \\
\text { Bandwid } \\
\text { th }\end{array}$} & $\begin{array}{l}\text { Fast } \\
\text { Ethernet }\end{array}$ & 16685.2 \\
\hline & & & & $802.11 n$ & 117920 \\
\hline & & \multirow{6}{*}{8} & \multirow{2}{*}{$\begin{array}{l}25 \% \quad \mathrm{x} \\
\text { Total } \\
\text { Bandwid } \\
\text { th }\end{array}$} & $\begin{array}{l}\text { Fast } \\
\text { Ethernet }\end{array}$ & 73.1374 \\
\hline & & & & $802.11 n$ & 18077.5 \\
\hline & & & \multirow{2}{*}{$\begin{array}{l}50 \% \quad \mathrm{x} \\
\text { Total } \\
\text { Bandwid } \\
\text { th }\end{array}$} & $\begin{array}{l}\text { Fast } \\
\text { Ethernet }\end{array}$ & 135.755 \\
\hline & & & & $802.11 n$ & 35183.5 \\
\hline & & & \multirow{2}{*}{$\begin{array}{l}75 \% \quad \mathrm{x} \\
\text { Total } \\
\text { Bandwid } \\
\text { th }\end{array}$} & $\begin{array}{l}\text { Fast } \\
\text { Ethernet }\end{array}$ & 683.041 \\
\hline & & & & $802.11 n$ & 53365 \\
\hline & & \multirow{6}{*}{16} & \multirow{2}{*}{$\begin{array}{l}25 \% \quad \mathrm{x} \\
\text { Total } \\
\text { Bandwid } \\
\text { th } \\
\end{array}$} & $\begin{array}{l}\text { Fast } \\
\text { Ethernet }\end{array}$ & 41.4668 \\
\hline & & & & $802.11 n$ & 8662.02 \\
\hline & & & \multirow{2}{*}{$\begin{array}{l}50 \% \quad \mathrm{x} \\
\text { Total } \\
\text { Bandwid } \\
\text { th }\end{array}$} & $\begin{array}{l}\text { Fast } \\
\text { Ethernet }\end{array}$ & 81.83 \\
\hline & & & & $802.11 n$ & 17883.5 \\
\hline & & & \multirow{2}{*}{$\begin{array}{l}75 \% \quad \mathrm{x} \\
\text { Total } \\
\text { Bandwid } \\
\text { th }\end{array}$} & $\begin{array}{l}\text { Fast } \\
\text { Ethernet }\end{array}$ & 127.784 \\
\hline & & & & $802.11 n$ & 23250.1 \\
\hline & & \multirow{4}{*}{32} & \multirow{2}{*}{$\begin{array}{l}25 \% \quad \mathrm{x} \\
\text { Total } \\
\text { Bandwid } \\
\text { th }\end{array}$} & $\begin{array}{l}\text { Fast } \\
\text { Ethernet }\end{array}$ & 23.8764 \\
\hline & & & & $802.11 n$ & 4276.78 \\
\hline & & & \multirow{2}{*}{$\begin{array}{l}50 \% \quad \mathrm{x} \\
\text { Total } \\
\text { Bandwid } \\
\text { th }\end{array}$} & $\begin{array}{l}\text { Fast } \\
\text { Ethernet }\end{array}$ & 44.4094 \\
\hline & & & & $802.11 n$ & $\begin{array}{l}8518.71 \\
522 \\
\end{array}$ \\
\hline
\end{tabular}


RESISTOR (Elektronika Kendali Telekomunikasi Tenaga Listrik Komputer) Vol. 4 No. 1 e-ISSN : 2621-9700, p-ISSN : 2654-2684

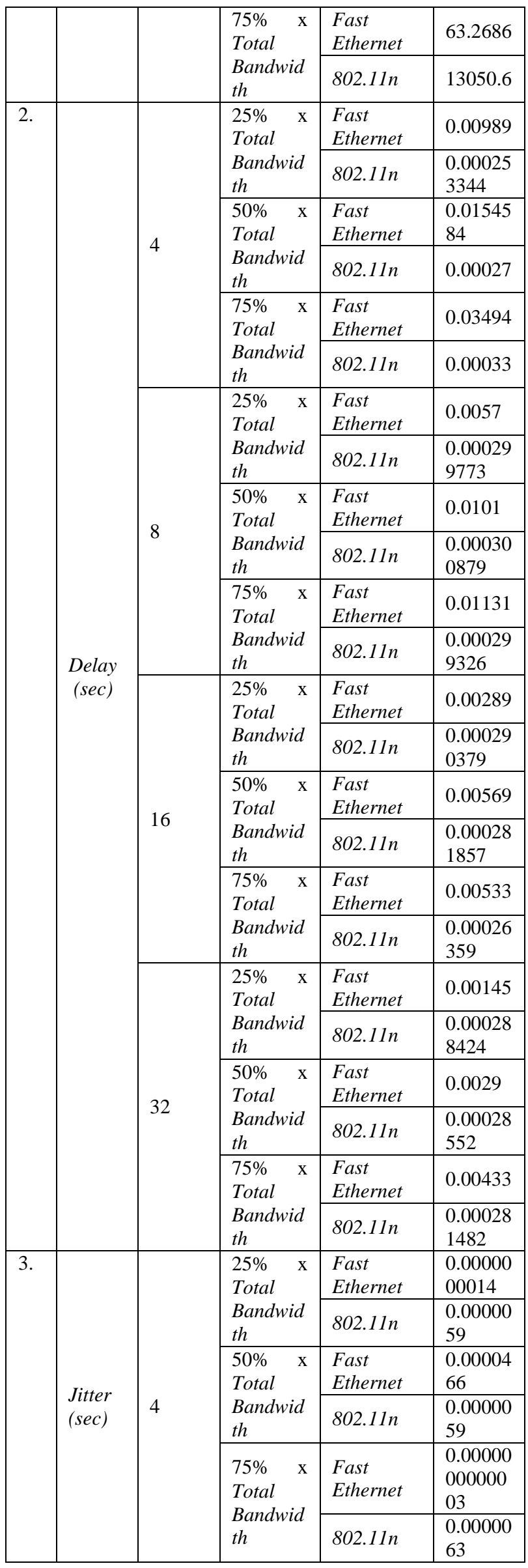

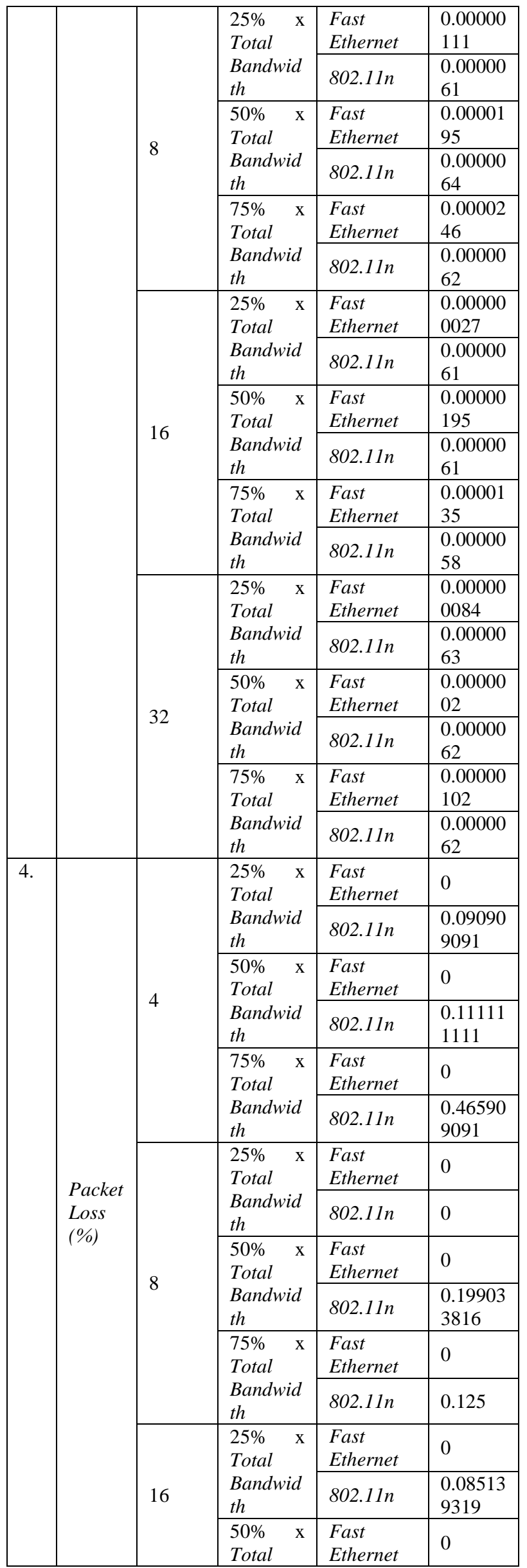


RESISTOR (Elektronika Kendali Telekomunikasi Tenaga Listrik Komputer) Vol. 4 No. 1 e-ISSN : 2621-9700, p-ISSN : 2654-2684

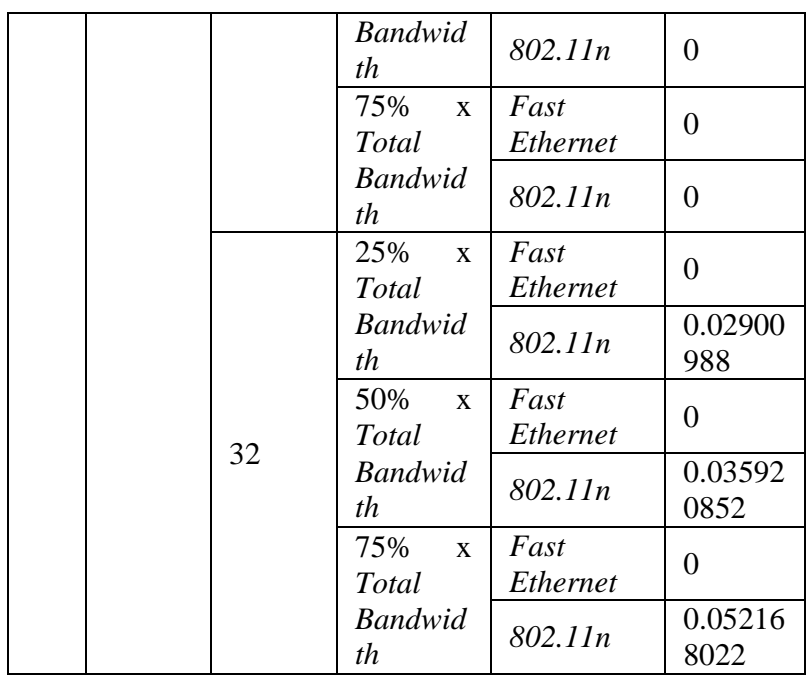

\section{KESIMPULAN}

Dari hasil simulasi dan analisa yang telah dilakukan maka dapat disimpulkan sebagai berikut :

Berdasarkan perbandingan skenario yang telah dilakukan, semakin banyak jumlah client yang melakukan transfer data dengan jumlah besar, maka nilai throughput akan semakin besar. Jaringan Wireless 802.11n dengan jumlah 32 client dan besar transfer data $75 \%$ dari total bandwidth memiliki skenario terbaik pada parameter throughput. Semakin sedikit jumlah client yang melakukan transfer data dengan jumlah kecil, maka nilai delay akan semakin kecil. Jaringan Wireless $\quad 802.11 \mathrm{n}$ dengan jumlah 4 client dan besar transfer data $25 \%$ dari total bandwidth memiliki skenario terbaik pada parameter delay. Semakin sedikit jumlah client yang melakukan transfer data dengan jumlah besar, maka nilai jitter akan semakin mendekati angka 0 sec. Jaringan Wireless $802.11 \mathrm{n}$ dengan jumlah 4 client dan besar transfer data $75 \% \mathrm{x}$ total bandwidth memiliki skenario terbaik pada parameter jitter.

TCP Window Size 64k menggunakan TCP New Reno pada jaringan Wired Fast Ethernet mempunyai kabel yang melindungi data saat di kirim dari FTP server ke client sehingga mengalami jaringan yang lebih stabil, selain itu juga jarang mengalami packet loss, namun lebih lambat dalam waktu pengiriman datanya daripada jaringan Wireless 802.11n. Hal ini terjadi pada hasil simulasi dan analisa yang telah dilakukan, dimana nilai average jitter terbaik dengan nilai average 0,0000000000003 sec. Packet loss terbaik pada keseluruhan skenario pada jaringan Wired Fast Ethernet dengan nilai average packet loss $0 \%$.

TCP Window Size 64k menggunakan TCP New Reno pada jaringan Wireless 802.11n menggunakan gelombang udara dalam proses transmisi data, sehingga jaringan dapat dikirim dan diterima lebih cepat, selain itu juga Wireless 802.11n mempunyai bandwidth yang lebih besar daripada Wired Fast Ethernet sehingga jaringan yang dikirim dan diterima lebih besar daripada Wired Fast Ethernet, namun lebih sering terjadi paket yang hilang daripada jaringan Wired Fast Ethernet. Hal ini terjadi pada hasil simulasi dan analisa yang telah dilakukan dimana nilai average throughput terbaik dengan nilai average 13050,6 bit/sec, adapun delay terbaik sebesar 0,000253 sec.

Berdasarkan pengaruh congestion control pada algoritma TCP New Reno, jika terjadi multi paket drop maka algoritma ini akan bertahan di fase fast recovery. Sehingga nilai throughput yang dihasilkan tetap tinggi. Kemudian, Algoritma TCP New Reno akan memperkecil delay dari yang seharusnya agar lebih cepat terdeteksi adanya packet loss dan cepat untuk dikirimkan kembali kepada client (fast retransmit).

\section{SARAN}

Beberapa saran untuk perkembangan bagi penelitian selanjutnya seperti yaitu penelitian selanjutnya dapat dilakukan dengan menggunakan layanan HTTP, Email, Remote login dan DB Query. Penelitian selanjutnya dapat dilakukan dengan menggunakan topologi lain, seperti topologi tree, mesh, maupun bus pada jaringan wired. Penelitian selanjutnya dapat dilakukan dengan menggunakan jumlah transfer data sebesar $100 \%$ dari besar bandwidth.

\section{REFERENSI}

[1] T. Mahardian Bangkit Sugiri, "Analisis Perbandingan Unjuk Kerja TCP Reno dan TCP Vegas pada Jaringan Kabel,” 2016.

[2] A. Siswanto, "Evaluasi Kinerja Wireless 802.11N untuk E Learning," ITJRD, vol. 1, no. 2, hlm. 13-25, Feb 2017, doi: 10.25299/itjrd.2017.vol1(2).557.

[3] K. R. A. Manibuy, "Analisis Perbandingan Unjuk Kerja TCP Tahoe dan TCP New Reno pada Jaringan Wired dan Wireless,” 2017.

[4] A. Samuel Luceano Basylea Siahaan, "Analisis Perbandingan TCP Window Size Menggunakan Algoritma TCP Reno pada Jaringan Kabel,” 2020.

[5] H. Idwan, T. Y. Arif, dan R. Munadi, "Analisis Round Trip Time (RTT) Terhadap Kinerja Jaringan Wireless TCP New Reno," hlm. 9, 2018. 
RESISTOR (Elektronika Kendali Telekomunikasi Tenaga Listrik Komputer) Vol. 4 No. 1 e-ISSN : 2621-9700, p-ISSN : 2654-2684

[6] "OPNET Network Simulator," Opnet Projects. http://opnetprojects.com/opnetnetwork-simulator/.

[7] M. K. Hanif, S. M. Aamir, R. Talib, dan Y. Saeed, "Analysis of Network Traffic Congestion Control over TCP Protocol," hlm. 10, 2017.

[8] H. Riyadi, "Kabel Jaringan: Pengertian, Fungsi, Kelebihan dan Kekurangannya," Nesabamedia, Sep 14, 2017. https://www.nesabamedia.com/pengertiankabel-jaringan/

[9] A. T. Harfad, S. R. Akbar, dan A. Bhawiyuga, "Analisa Kinerja Algoritma TCP Congestion Control Cubic, Reno, Vegas Dan Westwood+," hlm. 10.

[10] Y. H. Putra, "Simulasi dan Analisa Pengaruh TCP Windowing pada Transport Layer Terhadap Peningkatan Kinerja Jaringan Berbasis Virtual Private Network (VPN) Menggunakan Simulator OPNET," hlm. 87, 2010 .

[11] Anonym, "Mikrotik.ID : TCP/IP (Bagian 2) : $\quad$ Protokol." http://mikrotik.co.id/artikel_lihat.php?id=62 (diakses Des 22, 2019).

[12] G. A. Ryandy, "Analisis Perbandingan Unjuk Kerja Algoritma TCP New Reno dengan TCP Westwood+ Untuk Mereduksi Kongesti pada Jaringan WLAN."

[13] Y. T. Nugroho, "Analisis Unjuk Kerja TCP pada Finite Buffer dan Infinite Buffer," 2018.

[14] M. ibnu R. Febriansah, "Analisis Bottleneck dan Bufferbloat pada AQM Droptail,RED dan SFQ di Komunikasi Data TCP Newreno," JR, vol. 2, no. 9, Agu 2020, doi: 10.22219/repositor.v2i9.748.

[15] M. Taruk dan H. J. Setyadi, "Analisis Mekanisme Penanganan Kemacetan (Congestion Control) pada Algoritma Varian Protokol TCP," hlm. 5, 2016.

[16] E. Prasetyo, A. Hamzah, dan E. Sutanta, "Analisa Quality of Service (QOS) Kinerja Point to Point Protocol Over Ethernet (PPPOE) dan Point to Point Tunneling Protocol (PPTP)," vol. 4, no. 1, hlm. 10, 2016.

[17] D. Ruwaida dan D. Kurnia, "Rancang Bangun File Transfer Protocol (FTP) dengan
Pengaman Open SSL pada Jaringan VPN Mikrotik di SMKS Dwiwarna," CESS (Journal of Computer Engineering System and Science), vol. 3, 2018.

[18] F. Rofii, F.- Hunaini, dan S. Sholawati, "Kinerja Jaringan Komunikasi Nirkabel Berbasis Xbee pada Topologi Bus, Star dan Mesh," ELKOMIKA, vol. 6, no. 3, hlm. 393, Okt 2018, doi: 10.26760/elkomika.v6i3.393.

[19] E. F. Cahyadi, R. D. Cahyani, dan A. Hikmaturokhman, "Analisa Karakteristik Teori Antrian pada Jaringan IP Multimedia Subsystem (IMS) Menggunakan OPNET Modeler 14.5," hlm. 9, 2015. 
RESISTOR (Elektronika Kendali Telekomunikasi Tenaga Listrik Komputer) Vol. 4 No. 1 e-ISSN : 2621-9700, p-ISSN : 2654-2684 